\author{
М.В. Качан ${ }^{1}$, В.В. Кулибаба ${ }^{2}$, В.П. Байдацький ${ }^{2}$ В.Б. Білоус ${ }^{2}$, О.А. Бойко ${ }^{2}$ \\ ${ }^{1}$ Харківський національний університет Повітряних Сил ім. І. Кожедуба, Харків \\ ${ }^{2}$ Національний університет оборони Украйни ім. I. Черняховського, Київ
}

\title{
НАУКОВО-МЕТОДИЧНИЙ АПАРАТ УПРАВЛІННЯ СИСТЕМОЮ ГЕОПРОСТОРОВОЇ РОЗВІДКИ ІЗ ЗАСТОСУВАННЯМ СИСТЕМНО-КОГНІТИВНОГО АНАЛІЗУ
}

На практиці постійно виникає проблема поєднання даних від різних видів розвідки, щуоб отримати максимально повну, точну та достовірну інформацію. Дану проблему вирішує геопросторова розвідка. Це в свою чергу вимагає відповідного рівня автоматизації процесів управління, добування та обробки даних. У статті розроблено науково-методичний апарат з використанням системно-когнітивного аналізу для визначення векторного критерію при розв'язанні задачі стійкого управління, визначення цінності $і$ впливу вхідних параметрів на функціонування та вибору стратегї управління системою геопросторової розвідки.

Ключові слова: автоматизачія управління, відомості, дані, інформація, розвідувальні матеріали, система геопросторової розвідки.

\section{Вступ}

Постановка проблеми. Сучасні наукові підходи щодо побудови комплексної оцінки якості автоматизованого управління не можливі без застосування методології системного аналізу. Системний аналіз забезпечує повноту та всебічність дослідження складної системи, дозволяє поєднати в одне ціле множину процесів, що відбуваються у різних сфеpax, наприклад економічній, соціальній, екологічній, воєнній. На сьогодні усі зв'язки між складними системами воєнного призначення є слабо формалізованими і досліджуються, як правило, розрізнено. При цьому найбільш складна система $є$ слабко структурованою та багатозв'язною. Виходячи з цього, на думку авторів пропонується застосування системно-когнітивного аналізу для опису і дослідження подібних систем [1-3].

Аналіз останніх досліджень і публікацій. Система геопросторової розвідки (ГПР) є складовою частиною системи воєнної розвідки та загальної системи моніторингу суміжних 3 Україною держав, коаліцій і блоків держав та існує у просторі функцій, які деталізуються у типовий комплекс завдань, що виконуються за рахунок композиції внутрішніх функцій та базових інформаційно-технологічних алгоритмів функціонування системи. В свою чергу, автоматизація ГПР спрямована на підвищення ефективності функціонування системи в цілому.

При розробці автоматизованої системи управління ГПР пріоритетне значення має побудова коректної математичної моделі об’єкту управління.

В [4-5] показано, що система ГПР є багатоцільовою сблабоструктурованою системою у функціонуванні якої виділяють детерміновані та біфуркаційні етапи. Управління такою системою багатокритеріальна задача, розв'язання якої ускладнюється необхідністю врахування групових переваг осіб, що приймають участь у процесі прийняття рішень. Якість розв'язання задачі підтримки прийняття рішення в процесі управління не може оцінюватись однією функцією і навіть декількома шкалами [6-7].

Механізм раціонального вибору у таких випадках вимагає додаткової непрямої інформації, що дозволяє, принаймні, порівнювати альтернативи вибору стратегій управління. Отже необхідним $є$ постановка та вирішення проблеми стійкого управ-

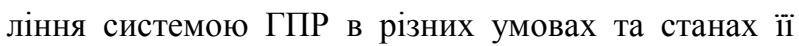
функціонування на основі системно-когнітивного аналізу [8; 10-11].

Теоретичні дослідження обчислювальних методів теорії прийняття рішення [1-2; 5; 7] доводять важливість визначення вимог до процедури формування векторного критерію. До цих вимог відносять повноту множини критеріїв, ненадлишковість, здатність до розкладання, мінімальність, можливість вимірювання.

Процедура побудови такого векторного критерію досить складна, неоднозначна і подекуди неформалізована.

Метою статті $\epsilon$ удосконалення науковометодичного апарату управління системою геопросторової розвідки на основі використання системнокогнітивного аналізу для визначення векторного критерію при розв'язанні задачі стійкого управління, визначення цінності і впливу вхідних параметрів на функціонування та вибір стратегії управління системою ГПР. 


\section{Виклад основного матеріалу}

Для опису слабо структурованих, слабо формалізованих і багатозв'язних систем великої розмірності найзручнішими є “м'які” моделі [12-13], що дозволяють здійснити повну формалізацію окремих процесів та отримати строго формальне представлення системи. Для описання когнітивних моделей ефективно використовується апарат знакових та зважених орієнтованих графів [12].

$$
\Phi=\langle G, X, F, \theta\rangle,
$$

де $\Phi$-модель системи, яка досліджується; $G-$ знаковий орієнтовний граф;

$X$ - множина параметрів вершин.

$$
\begin{aligned}
& X=\left\{X^{\left(V_{i}\right)} \mid X^{\left(V_{i}\right)} \in X, i=1,2, \ldots, k\right\}, \\
& X^{\left(V_{i}\right)}=\left\{x_{g}^{(i)}\right\}, g=1,2, \ldots, l,
\end{aligned}
$$

де $V$ - множина вершин, вершини (концепти) $V_{i} \in V, i=1,2, \ldots, k \in$ елементами системи, що досліджується;

$x_{g}^{(i)}, g$ - параметр вершини $V_{i}$, якщо $g=1$, то $x_{g}^{(i)}=x_{j} ; \theta-$ простір параметрів вершин;

$F$ - функціонал перетворення дуг, що ставить у відповідність кожній дузі або знак (“+”, “-”), або ваговий коефіцієнт $\omega_{i j}$, або функцію $f\left(x_{i}, x_{j}, e_{i j}\right)=f_{i j}$.

Залежність $f_{i j}$ може бути не тільки функціональною, а й стохастичною $\eta_{i j}$. По мірі накопичення знань про процеси стає можливим більш детально розкрити характер зв'язків між факторами.

При цьому будь-яка “м'яка” модель у математичній постановці задачі $€$ феноменологічною 3 набором “чорних ящиків" із заданими входами i визначеними виходами та пов'язаними між собою законом проходження інформації.

У цьому сенсі інформаційна модель системи представляється у вигляді когнітивної карти. У відповідності 3 [2-3;12] під когнітивною картою розуміється математична модель, яка представлена у вигляді графу та дозволяє здійснювати описання будь-якого складного об'єкту, проблеми або процесу функціонування системи.

$$
G=\langle V, E\rangle,
$$

де $G$ - знаковий орієнтовний граф (когнітивна карта);

$$
E=\left\{e_{i} \mid e_{i} \in E, i=1,2, \ldots, k\right\} \text { - множина дуг, де }
$$

дуги $e_{i j} \in E, i, j=1,2, \ldots, N$ відображують взаємозалежність між вершинами $V_{i}$ на $V_{j}$, яка в залежності від ситуації може бути позитивною, негативною або відсутньою. Системно-когнітивний аналіз призначений для визначення структури причинних зв'язків між елементами системи, складного об'єкту або складовими проблеми та оцінювання наслідків, що відбуваються внаслідок впливу на ці елементи або внаслідок зміни характеру зв'язків. Ваги дуг у суто когнітивних моделях визначаються з використанням статистичної обробки інформації, або експертним шляхом. Зміна факторів відбувається окремо для кожного шару до визначення реакції системи, після чого $з$ використанням багатокритеріального вибору визначається множина сприятливих сценаріїв [13-14]. Для відображення динаміки функціонування системи під впливом оточуючого середовища у модель вводиться час. Нехай параметр $x_{i}$ залежить від часу, тобто $x_{i}(t), t=1,2,3, \ldots, T$, де $T$ - кількість дискрет моментів часу. Тоді можна визначити процес розповсюдження збурення по графу, тобто перехід системи із стану $t-1$ у стан $t$, та у стан $t+1$, за правилом зміни параметрів у вершинах в момент $t_{n+1}$, якщо в момент часу $t_{n}$ на вершини подано імпульси $P\left(t_{n}\right)$.

$$
\begin{gathered}
x_{i}\left(t_{n+1}\right)=x_{i}\left(t_{n}\right)+ \\
+\sum_{v_{j}: e=e_{i j} \in E}^{k-1} f\left(x_{i}, x_{j}, e_{i j}\right) P_{j}\left(t_{n}\right)+A_{i}\left(t_{n+1}\right),
\end{gathered}
$$

де $A_{i}\left(t_{n+1}\right)$ - множина правил зміни параметрів у вершинах в момент $t_{n+1}$.

Враховуючи вирази (1)-(3) формалізовану модель системи можна описати у вигляді кортежу:

$$
S=\langle a, S t, t P s, C O, t t\rangle,
$$

де $S$ - система, що досліджується;

$a$-мета функціонування системи; $S t-$ структура системи;

$\mathrm{CO}$ - умови досягнення мети; $t t-$ час досягнення мети;

$t P s$ - множина процесів, які реалізуються відповідними засобами на основі методів обробки інформації (генерування інформації, іiі передавання, сприйняття, розуміння, розпізнавання, зберігання, пошук, висновок, прогнозування, тощо).

При цьому:

$$
t P s=\langle m e t, r c, P p, I s\rangle,
$$

де $m e t$ - методи досягнення мети;

$r c$ - засоби досягнення мети;

$P p$ - зворотна інформація про реакцію системи;

Is - інформація про систему.

Виходячи 3 формул (3) - (5) метою управління $\epsilon$ забезпечення бажаних змін цільових факторів у процесі прийняття рішення управління системою у конкретній обстановці.

Отже методика когнітивного аналізу містить наступні етапи: 
1. Формулювання задач і мети дослідження.

2. Здійснення системного концептуального дослідження.

3. Здійснення структурування знань про предметну область.

4. Побудова когнітивної моделі системи, що досліджується.

5. Здійснення структурного аналізу когнітивної моделі.

6. Здійснення моделювання, що засноване на когнітивному підході.

7. Здійснення предметної інтерпретації результатів моделювання.

3 точки зору технічної реалізації сутність запропонованої методики полягає у здійсненні когнітивного моделювання i аналізу складної системи. У цьому аспекті під моделюванням слід розуміти засіб для отримання теоретичних і практичних знань про проблему і формулювання на цій основі практичних висновків. Моделювання являє собою циклічний процес, що базується на сценарному підході [14].

Під сценарієм розуміється сукупність тенденцій, що характеризують поточну ситуацію, бажаних цілей розвитку, комплексу заходів, що впливають на розвиток ситуації і системи параметрів (факторів), які спостерігаються та ілюструють поведінку процесів [2-3; 12]. Процес системно-когнітивного аналізу і моделювання містить такі етапи:

1. Визначення початкових умов, тенденцій розвитку ситуації на визначеному етапі.

2. Визначення цільових напрямків і сили зміни тенденцій процесів у ситуації.

3. Вибір комплексу заходів.

4. Вибір комплексу можливих впливів на ситуацію.

5. Вибір факторів, які характеризують розвиток ситуації.

На рис. 1 зображено технологію системнокогнітивного аналізу i моделювання. Основна складність побудови когнітивної карти для формування векторного критерію ефективності функціонування системи ГПР полягає у великій кількості факторів (концептів). Зазвичай для скорочення кількості концептів їх ранжирують за важливістю і обирають найважливіші.

У роботах $[2-3 ; 8 ; 12]$ викладена методологія проведення дослідження вибору найбільш значимих критеріїв ефективності функціонування системи управління складними системами військового призначення. Формування векторного критерію методом когнітивних карт зазвичай здійснюється в три етапи $[2-3 ; 8 ; 12]$ :
1. Формування переліку концептів.

2. Визначення відношень причиннонаслідкових зв'язків між концептами.

3. Узгодження значень відношень причиннонаслідкових зв'язків між концептами.

В результаті опитування експертів 3 урахуванням результатів наукових досліджень $[1-3 ; 9 ; 12]$ була визначена множина найбільш важливих концептів (факторів), що описують якість функціонування системи ГПР (табл. 2).

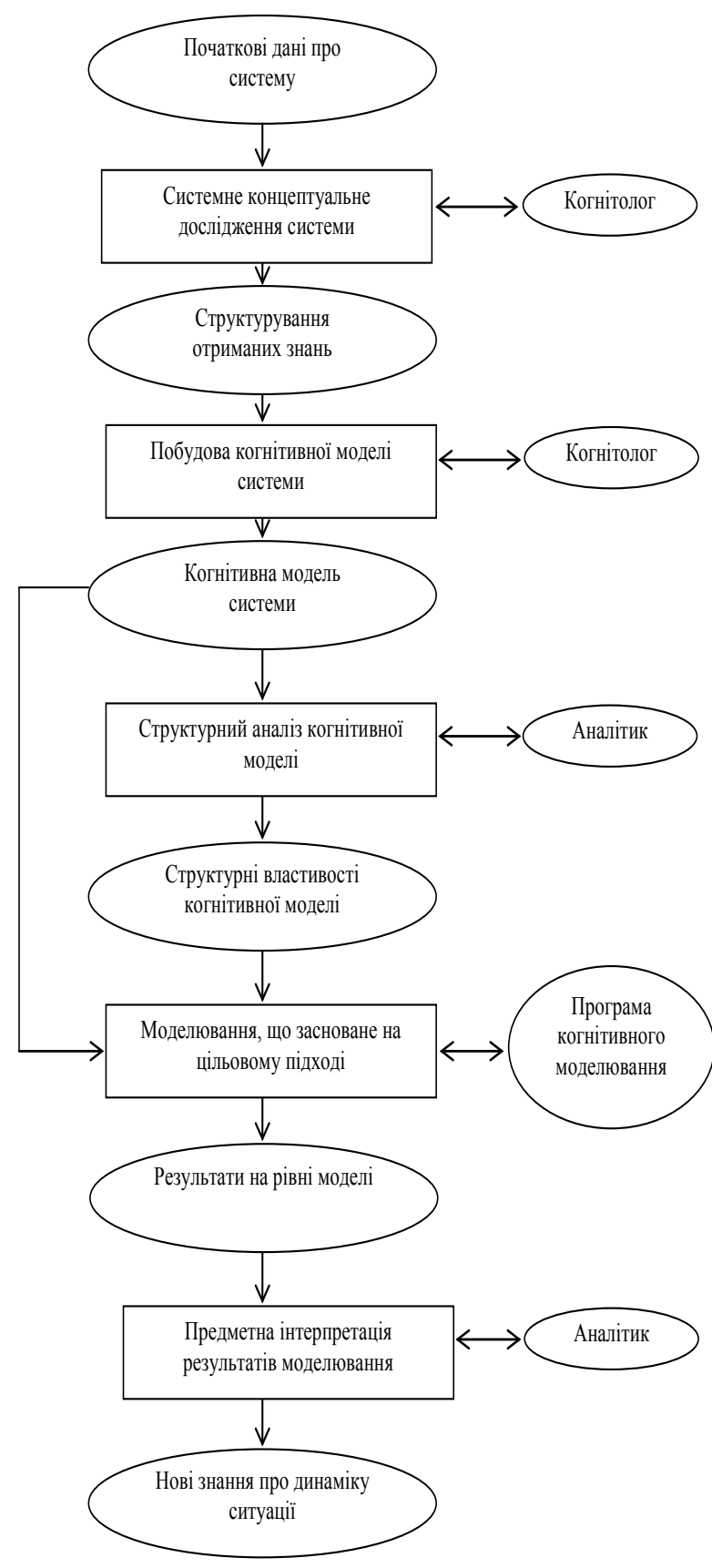

Рис. 1. Технологія когнітивного аналізу і моделювання [14] 
Концепти, що описують якість функціонування системи ГПР

\begin{tabular}{|c|c|c|}
\hline $\begin{array}{l}\text { № } \\
\text { 3/ח }\end{array}$ & Концепт & Сутність концепту \\
\hline 1. & $\begin{array}{c}\text { Показник } \\
\text { ефективності }\end{array}$ & $\begin{array}{l}\text { Ефективність } E=\phi\left(\Pi_{Б M}\right), \\
\text { де } \Pi_{Б M}-\text { показники можливостей. Ступінь реалізації можливостей } K_{P Б M}=\sum_{i=1}^{n} W_{i} K_{i} \text {, } \\
\text { при цьому } \sum_{i=1}^{n} W_{i}=1 \text {, де } W_{i}-\text { ваговий коефіцієнт } i \text {-го виду показника можливостей; } n- \\
\text { кількість показників можливостей. }\end{array}$ \\
\hline 2. & $\begin{array}{l}\text { Повнота } \\
\text { оцінювання } \\
\text { противника } \\
\text { (прийнятих } \\
\text { рішень) }\end{array}$ & 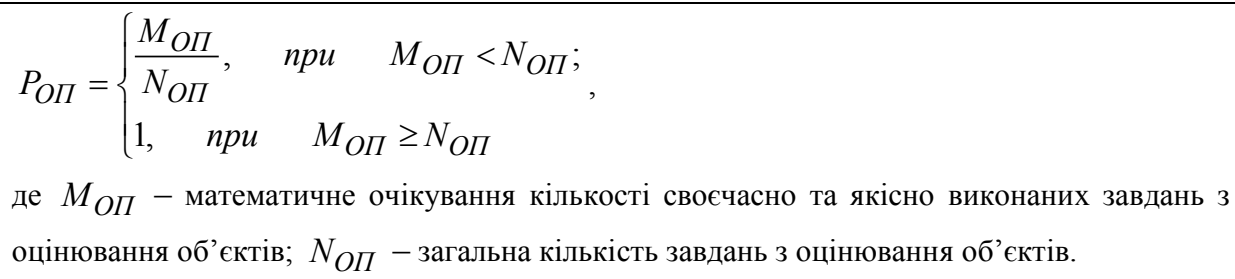 \\
\hline 3. & $\begin{array}{l}\text { Достовірність } \\
\text { оцінювання } \\
\text { (прийняття } \\
\text { рішення) }\end{array}$ & 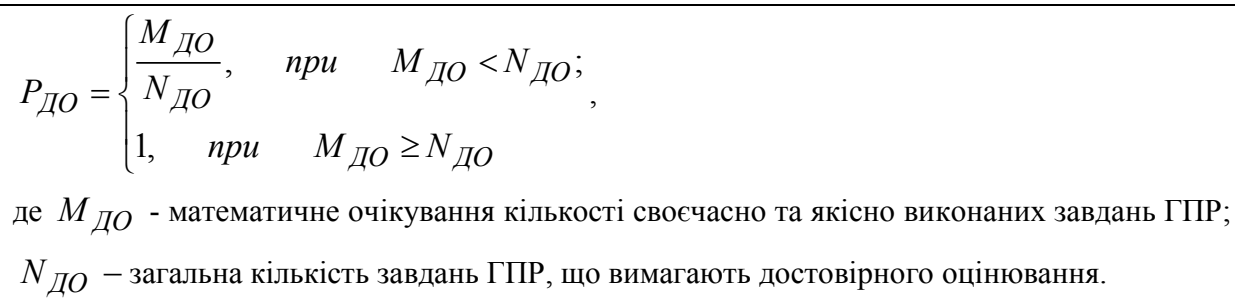 \\
\hline 4. & $\begin{array}{l}\text { Своєчасність } \\
\text { оцінювання } \\
\text { (прийняття } \\
\text { рішення) }\end{array}$ & 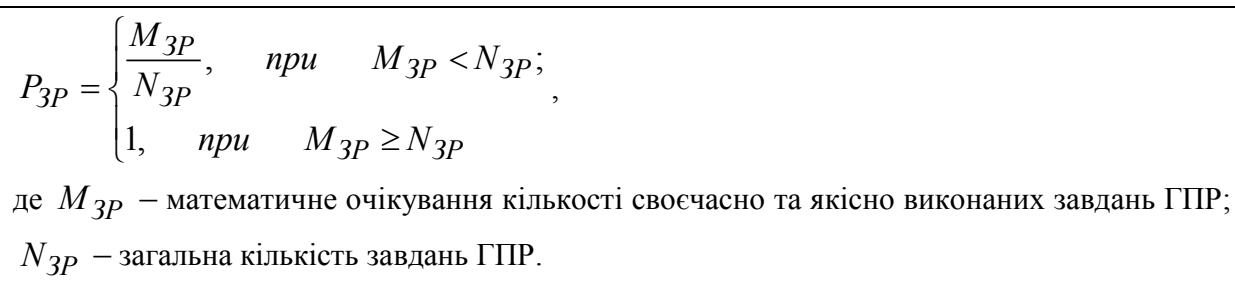 \\
\hline 5. & Цілеспрямованість & $\begin{array}{l}P_{Ц}=W_{3 P} P_{3 P}+W_{\kappa б м} K_{P Б M}, \\
\text { де } W_{3 P}-\text { матриця вагових коефіцієнтів завдань ГПР; } W_{\kappa б м}-\text { матриця вагових } \\
\text { коефіцієнтів бойових можливостей ГПР. }\end{array}$ \\
\hline 6. & Безперервність & $\begin{array}{l}P_{H}=W_{n p ч} K_{n p ч}+W_{\kappa б м} K_{\text {РБM }}, \\
\text { де } K_{n p ч}-\text { просторово-часові показники можливостей; } W_{n p ч}-\text { матриця вагових } \\
\text { коефіцієнтів просторово-часових показників можливостей ГПР. }\end{array}$ \\
\hline 7. & Активність & $\begin{array}{l}P_{A}=W_{O M(Д Р M)} \sum_{i=1}^{m} \frac{N_{i}}{N_{i 0}}+W_{O M(Д Р M)} \frac{N_{\text {нов }}}{N_{0}}, \\
\text { де } W_{O M(Д Р M)}-\text { матриця вагових коефіцієнтів важливості об’єктів ГПР (джерел ГПР); } \\
N_{i} \text { - кількість виявлених об'єктів ГПР; } N_{i 0} \text { - загальна кількість групових об'єктів ГПР; } \\
N_{\text {нов }} \text { - кількість виявлених нових об’єктів ГПР за час }\left[t_{n-1}, t_{n}\right] ; N_{0} \text { - загальна кількість } \\
\text { не викритих об'єктів ГПР на час } t_{n} .\end{array}$ \\
\hline 8. & Прихованість & $\begin{array}{l}P_{\Pi}=P_{б з}=1-P_{6 m}, \\
\text { де } P_{б з}-\text { імовірність забезпечення сил і засобів ГПР; } P_{в m}-\text { коефіцієнт (імовірність) втрат } \\
\text { за встановлений час. }\end{array}$ \\
\hline 9. & $\begin{array}{l}\text { Точність } \\
\text { визначення } \\
\text { координат }\end{array}$ & $\begin{array}{l}P_{T}=\sum_{i=1}^{I} W_{T i} \cdot K_{T i}, \\
\text { де } K_{T i}-\text { ступінь забезпечення будь-яких точнісних показників для вирішення завдань; } \\
W_{T i}-\text { вагові коефіціснти завдань. }\end{array}$ \\
\hline
\end{tabular}


Закінчення табл. 1

\begin{tabular}{|c|c|c|}
\hline 10. & $\begin{array}{l}\text { Апаратурна } \\
\text { доступність } \\
\text { джерел }\end{array}$ & $\begin{array}{l}P_{A Д}=W_{\text {Дж }} \sum_{i=1}^{m} \frac{D_{i}}{N_{i 0}} \\
\text { де } D_{i}-\text { кількість доступних джерел за апаратурною доступністю; } W_{\text {Дж }}-\text { матриця ваго- } \\
\text { вих коефіцієнтів важливості джерел ГПР. }\end{array}$ \\
\hline 11. & $\begin{array}{l}\text { Інформативна } \\
\text { доступність } \\
\text { джерел }\end{array}$ & $\begin{array}{l}P_{\text {ІД }}=W_{\text {Дж }} \sum_{i=1}^{m} \frac{L_{i}}{N_{i 0}} \\
\text { де } L_{i}-\text { кількість інформативно доступних джерел; } W_{\text {Дж }}-\text { матриця вагових коефіцієнтів } \\
\text { важливості ГПР. }\end{array}$ \\
\hline 12. & Кількість постів & $N_{\Pi}$ \\
\hline 13. & $\begin{array}{c}\text { Матеріальні } \\
\text { витрати }\end{array}$ & $\begin{array}{l}P_{M B}=\sum_{j=1}^{b} W_{M B j} \cdot K_{M B j}, \\
\text { де } W_{M B j}-\text { вагові коефіцієнти матеріальних витрат тих чи інших вимог до розвідки; } \\
K_{M B j}-\text { коефіцієнти (ступінь та імовірність) матеріальних витрат тих чи інших вимог до } \\
\text { ГПР; } b \text { - кількість загальних вимог до ведення ГПР. }\end{array}$ \\
\hline 14. & $\begin{array}{c}\text { Модернізація } \\
\text { озброєння }\end{array}$ & $\begin{array}{l}P_{M O}=\frac{N_{M 3}}{N_{3}} \cdot N_{\Pi}, \text { де } N_{M 3}-\text { кількість модернізованих засобів ГПР; } \\
N_{3} \text { - загальна кількість засобів ГПР. }\end{array}$ \\
\hline
\end{tabular}

Після визначення 14 змінних (концептів) було проведення опитування для визначення відношень причинності для кожної пари змінних $x, y$ з можливими базовими значеннями відношень причинності:

Знак “+” - означає, що зростання змінної $x$ призведе до зростання змінної $y$.

Знак “-” - означає, що зростання змінної $x$ призведе до зменшення змінної $y$.

Знак "0” - означає, що зростання змінної $x$ не впливає на значення змінної $y$.

Результати опитування наведені у табл. 2.

Таблиця 2

Матриця суміжності знакового орієнтованого графу

\begin{tabular}{|c|c|c|c|c|c|c|c|c|c|c|c|c|c|c|}
\hline$i / j$ & 1. & 2. & 3. & 4. & 5. & 6. & 7. & 8. & 9. & 10. & 11. & 12. & 13. & 14. \\
\hline 1. & 0 & + & + & + & 0 & 0 & 0 & 0 & 0 & 0 & 0 & 0 & - & + \\
\hline 2. & + & 0 & 0 & 0 & 0 & 0 & 0 & 0 & 0 & 0 & + & 0 & 0 & 0 \\
\hline 3. & + & 0 & 0 & - & 0 & 0 & 0 & 0 & 0 & 0 & 0 & 0 & 0 & 0 \\
\hline 4. & + & - & - & 0 & 0 & 0 & 0 & 0 & 0 & 0 & 0 & 0 & 0 & 0 \\
\hline 5. & + & + & + & + & 0 & 0 & + & 0 & 0 & 0 & 0 & 0 & 0 & + \\
\hline 6. & + & + & + & + & + & 0 & + & - & + & 0 & + & 0 & - & 0 \\
\hline 7. & + & + & + & + & + & + & 0 & - & + & 0 & + & 0 & 0 & 0 \\
\hline 8. & + & - & - & - & 0 & 0 & 0 & 0 & 0 & - & 0 & - & - & + \\
\hline 9. & + & + & + & 0 & 0 & 0 & 0 & 0 & 0 & 0 & + & + & - & + \\
\hline 10. & + & + & 0 & 0 & 0 & 0 & 0 & 0 & + & 0 & + & + & - & + \\
\hline 11. & + & + & + & + & 0 & 0 & 0 & 0 & 0 & 0 & 0 & 0 & - & + \\
\hline 12. & + & + & + & - & 0 & 0 & 0 & - & + & + & + & 0 & - & - \\
\hline 13. & + & 0 & 0 & 0 & + & 0 & + & 0 & 0 & 0 & 0 & 0 & 0 & + \\
\hline 14. & + & 0 & 0 & 0 & 0 & + & 0 & + & + & + & + & - & - & 0 \\
\hline
\end{tabular}

На основі табл. 2 побудовано знаковий орієнтований граф, який зображено на рис. 2.

Даний орієнтований граф використовується для якісного оцінювання впливу окремих вершин (концептів або критеріїв) на стійкість системи (векторного критерію). 


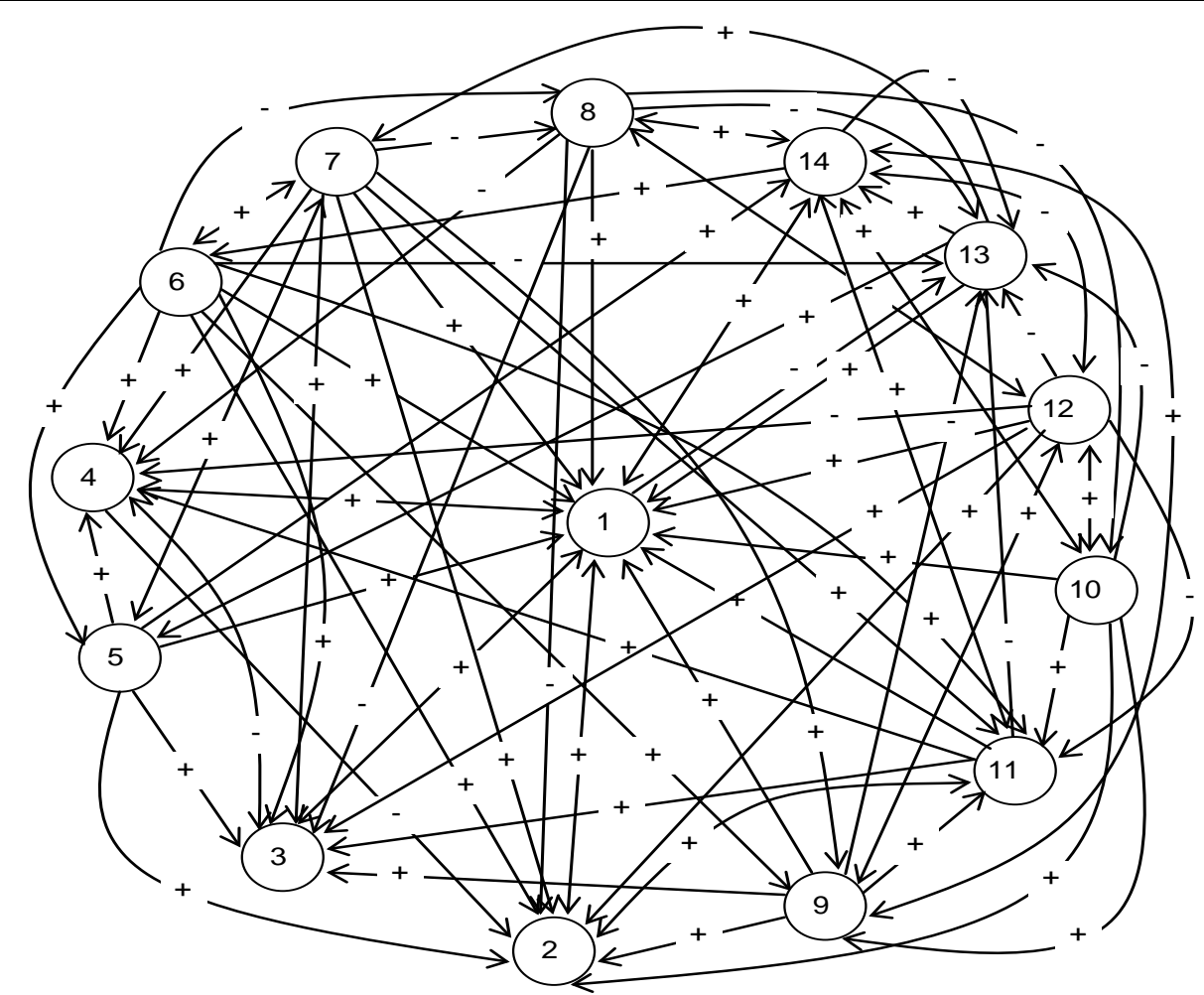

Рис. 2. Знаковий орієнтований граф розробленої когнітивної карти

Граф допомагає визначити, як зміниться стійкість системи, якщо деякі вершини здійснять достатньо сильний вплив на один або декілька концептів або змінять знак дуги.
Проведено аналіз знакового графу та визначено кількість додатних і від'ємних зворотних зв'язків та множину вершин, що не здійснюють вплив на інші (табл. 3).

Результати аналізу знакового графу

\begin{tabular}{|l|l|l|}
\hline \multicolumn{3}{|c|}{ Додатні зворотні зв'язки } \\
\hline $1+2+11+1$ & $1+2+11+3+1$ & $1+2+11+4+1$ \\
\hline $1-13+14+8-2+1$ & $1-13+14+8-3+1$ & $1-13+14+6-8+1$ \\
\hline $1-13+14+8-10+1$ & $1-13+14+8-12+1$ & $1-13+14+7-8+1$ \\
\hline $1-13+14+9-13+1$ & $1+3-4-2+1$ & $1-13+14+8-4+1$ \\
\hline $1-13+14-12+3+1$ & $1-13+14+8-13+1$ & $1-13+14-12+10+1$ \\
\hline $1-13+14-12+11+1$ & $1-13+14-12+2+1$ & $1-13+14-12+1$ \\
\hline & \multicolumn{2}{|c|}{ Від’ємні зворотні зв’язки } \\
\hline $1-13+14-12-4+1$ & $1-13+14-12-8+1$ & $1-13+14-12-14+1$ \\
\hline $1+3-4+1$ & $1+3-4+1$ & $1+4-2+1$ \\
\hline $1+4-3+1$ & $1-13+5+1$ & $1-13+5+2+1$ \\
\hline $1-13+5+3+1$ & $1-13+5+4+1$ & $1-13+5+7+1$ \\
\hline $1-13+5+14+1$ & $1-13+7+1$ & $1-13+7+2+1$ \\
\hline $1-13+7+3+1$ & $1-13+7+4+1$ & $1-13+7+5+1$ \\
\hline $1-13+7+6+1$ & $1-13+7-8+1$ & $1-13+7+9+1$ \\
\hline $1-13+7+11+1$ & $1-13+14+1$ & $1-13+14+6+1$ \\
\hline $1-13+14+6+2+1$ & $1-13+14+6+3+1$ & $1-13+14+6+4+1$ \\
\hline $1-13+14+6+5+1$ & $1-13+14+6+7+1$ & $1-13+14+7+1$ \\
\hline $1-13+14+6+9+1$ & $1-13+14+6+11+1$ & $1-13+14+7+4+1$ \\
\hline $1-13+14+7+2+1$ & $1-13+14+7+3+1$ & $1-13+14+8+1$ \\
\hline $1-13+14+7+5+1$ & $1-13+14+7+6+1$ & $1-13+14+9+2+1$ \\
\hline $1-13+14+7+9+1$ & $1-13+14+7+11+1$ & $1-13+14+9+12+1$ \\
\hline $1-13+14+8+14+1$ & $1-13+14+9+1$ & $1-13+14+10+1$ \\
\hline $1-13+14+9+3+1$ & $1-13+14+9+11+1$ & $14+10+11+1$ \\
\hline
\end{tabular}


Закінчення табл. 3

\begin{tabular}{|l|l|l|}
\hline $1-13+14+10+2+1$ & $1-13+14+9+14+1$ & $1-13+14+11+2+1$ \\
\hline $1-13+14+10+12+1$ & $1-13+14+10+9+1$ & $1-13+1$ \\
\hline $1-13+14+11+3+1$ & $1-13+14+11+1$ & $1-13+14+11+4+1$ \\
\hline $1-13+14-12+9+1$ & & \\
\hline
\end{tabular}

Результати когнітивного аналізу карти (рис. 2) вказують, що:

- всі обрані критерії (концепти) можуть бути використані в якості цільових;

- виділено 18 циклів, що підсилюють відхилення та 58 циклів, що стабілізують;

- за результатами аналізу (таблиця 3) можна здійснити прогнозування розвитку ситуацій в різних умовах обстановки.

\section{Висновки}

Таким чином, в статті удосконалений науковометодичний апарат управління системою геопросторової розвідки на основі використання системнокогнітивного аналізу для визначення векторного критерію при розв'язанні задачі стійкого управління, визначення цінності і впливу вхідних параметрів на функціонування та вибір стратегії управління системою ГПР. Технологія когнітивного аналізу i моделювання дозволила у складних і невизначених ситуаціях швидко, комплексно і системно охарактеризувати, обгрунтувати та на якісному рівні запропонувати шляхи розв'язання задачі управління системою геопросторової розвідки з урахуванням факторів навколишнього середовища.

Заповнення розробленої моделі конкретним змістом дозволить врахувати особливості функціонування системи ГПР та бажані напрямки іiі розвитку завдяки ранжування вершин за ступенем впливу на систему в цілому. При цьому, використовуючи даний підхід, в залежності від поставленого завдання, можна, знайти оптимальну стратегію управління системою ГПР за максимумом векторного критерію ефективності.

\section{Список літератури}

1. Ладанюк А.П. Системний аналіз складних систем управління / А.П. Ладанюк, Я.В. Смітюх, Л.О. Власенко. - К.: НУХТ, 2013. $-274 \mathrm{c}$.

2. Горелова Г.В. Когнитивный анализ, синтез, прогнозирование развития больших систем в интеллектуальных РИУС / Г.В. Горелова, Э.В. Мельник, Я.С. Коровин // Искусственный интеллект. - 2010. - № 3. - С. 61-72.

3. Авдеева 3.К. Когнитивное моделирование для решения задач управления слабоструктурированными системами (ситуациями) / З.К. Авдеева, С.В. Коврига, Д.И. Макаренко // Управление большими системами. - 2007. - № 16. C. 26-39.

4. Кучейко А.А. Развитие и конвергенция технологий геопространственной разведки / А.А. Кучейко // Сборник материалов ежегодной международной конференции “Оборона геопространственной разведки (DGI 2012)”. - Лондон, 2326 января 2012 г. - С. 96-97.

5. Попов М.О. Геопросторова розвідка в операціях збройних сил / М.О. Попов // Наука і оборона. - 2010. - № 2. -

6. Method of integral estimation of channel state in the multiantenna radio communication systems / S. Kalantaievska, H. Pievtsov, O. Kuvshynov, A. Shyshatskyi, S. Yarosh // Eastern-European Journal of Enterprise Technologies. - 2018. № 9(95). - P. 60-76. - https://doi.org/10.15587/1729-4061.2018.144085.

7. Воронин А.Н. Многокритериальные решения: модели и методы: монография / А.Н. Воронин, Ю.К. Зиатдинов, М.В. Куклинский. - К.: НАУ, 2011. - 268c.

8. Шуренок В.А. Методика оцінки космічної обстановки на базі нечіткої логіки / В.А. Шуренок // Збірник наукових праць. - 2003. - Ювілейний випуск. - С. 191-203.

9. Воронин А.М. Многокритериальный синтез динамических систем / А.М. Воронин. - К.: Наукова думка, 1992. $-160 \mathrm{c}$.

10. Визначення та основні поняття геопросторової розвідки / І.А. Кухарський, В.О. Подліпаєв, О.В. Атрасевич, В.О. Шумейко // Системи обробки інформації. - 2013. - № 6(113). - С. 96-98.

11. Подліпаєв В.О. Геопросторова розвідка, як шлях реалізації геоінформаційного підходу у комплексній обробці розвідувальної інформації / В.О. Подліпаєв // Системи обробки інформації. - 2013. - № 5(112). - С. 53-55.

12. Евстигнеев Д.В. Использование когнитивных моделей при построении комплексной оценки состояния территории [Електронний ресурс] / Д.В. Евстигнеев, Т.Н. Ледащева // Экономика и бизнес. - 2003. - Режим доступу: https://cyberleninka.ru/article/n/ispolzovanie-kognitivnyh-modeley-pri-postroenii-kompleksnoy-otsenki-sostoyaniya-territorii.

13. Робертс Ф.С. Дискретне математические модели с приложениями к социальным, биологическим и экологическим задачам / Ф.С. Робертс. - М.: Наука, 1986. - 496 с.

14. Бялецкая Е.М. О принципах когнитивного моделирования сложных систем / Е.М. Бялецкая, И.Ю. Квятковская // Весник Астраханского государственного технического университета. - 2006. - № 1(30). - С. 116-119. 


\section{References}

1. Ladaniuk, A.P., Smitiukh, Ya.V. and Vlasenko, L.O. (2013), "Systemnyi analiz skladnykh system upravlinnia" [System analysis of complex control systems], NUKhT, Kyiv, 274 p.

2. Gorelova, G.V., Mel'nik, E.V. and Korovin, Ya.S. (2010), "Kognitivnyi analiz, sintez, prognozirovanie razvitiya bol'shikh sistem v intellektual'nykh RIUS" [Cognitive analysis, synthesis, forecasting the development of large systems in intelligent RIUS], Artificial Intelligence, No. 3, pp. 61-72.

3. Avdeeva, Z.K., Kovriga, S.V. and Makarenko, D.I. (2007), "Kognitivnoe modelirovanie dlya resheniya zadach upravleniya slabostrukturirovannymi sistemami (situatsiyami)" [Cognitive modeling for solving problems of managing poorly structured systems (situations)], Large Systems Management, No. 16, pp. 26-39.

4. Kucheiko, A.A. (2012), "Razvitie i konvergentsiya tekhnologii geoprostranstvennoi razvedki" [Development and convergence of geospatial intelligence technologies], Annual Conference on Geospatial Intelligence and Geospatial Technologies Defense Geospatial Intelligence, 23-26 January, London, England, pp. 96-97.

5. Popov, M.O. (2010), "Heoprostorova rozvidka v operatsiiakh zbroinykh syl" [Geospatial intelligence in military operations], Science and Defense, No. 2, pp. 30-40.

6. Kalantaievska, S., Pievtsov, H., Kuvshynov, O., Shyshatskyi, A. and Yarosh, S. (2018), Method of integral estimation of channel state in the multiantenna radio communication systems, Eastern-European Journal of Enterprise Technologies, No. 9(95), pp. 60-76. https://doi.org/10.15587/1729-4061.2018.144085.

7. Voronin, A.N, Ziatdinov, Yu.K and Kuklinskii, M.V. (2011), "Mnogokriterial'nye resheniya: modeli i metody" [Multicriteria solutions: models and methods], NAU, Kyiv, $268 \mathrm{p}$.

8. Shurenok, V.A. (2003), "Metodyka otsinky kosmichnoi obstanovky na bazi nechitkoi lohiky" [Methods for assessing the cosmic situation on the basis of some logic], Collection of Scientific Works, pp. 191-203.

9. Voronin, A.M. (1992), "Mnogokriterial'nyi sintez dinamicheskikh system" [Multicriteria synthesis of dynamical systems], Naukova dumka, Kyiv, 160 p.

10. Kukharskyi, I.A., Podlipaiev, V.O., Atrasevych, O.V. and Shumeiko, V.O. (2013), "Vyznachennia ta osnovni poniattia heoprostorovoi rozvidky" [Definition and basic concepts of geospatial intelligence], Information Processing Systems, No. 6(113), pp. 96-98.

11. Podlipaiev, V.O. (2013), "Heoprostorova rozvidka, yak shliakh realizatsii heoinformatsiinoho pidkhodu u kompleksnii obrobtsi rozviduvalnoi informatsii" [Geospatial intelligence as a way to implement the geoinformation approach in the integrated processing of intelligence information], Information Processing Systems, No. 5(112), pp. 53-55.

12. Evstigneev, D.V. and Ledashcheva, T.N. (2003), "Ispol'zovanie kognitivnykh modelei pri postroenii kompleksnoi otsenki sostoyaniya territorii" [The use of cognitive models in the construction of a comprehensive assessment of the state of the territory], Economics and Business, available at: www.cyberleninka.ru/article/n/ispolzovanie-kognitivnyh-modeley-pripostroenii-kompleksnoy-otsenki-sostoyaniya-territorii.

13. Roberts, F.S. (1986), "Diskretne matematicheskie modeli s prilozheniyami k sotsial'nym, biologicheskim i ekologicheskim zadacham" [Discrete mathematical models with applications to social, biological and environmental problems], Nauka, Moscow, 496 p.

14. Byaletskaya, E.M. and Kvyatkovskaya, I.Yu. (2006), "O printsipakh kognitivnogo modelirovaniya slozhnykh system" [On the principles of cognitive modeling of complex systems], Bulletin of the Astrakhan State Technical University, No. 1(30), pp. 116-119.

\section{Відомості про авторів:}

\section{Качан Микола Віталійович}

доцент кафедри

Харківського національного університету

Повітряних Сил ім. І. Кожедуба,

Харків, Україна

https://orcid.org/0000-0003-3732-0369

\section{Кулибаба Володимир Вікторович}

слухач Національного університету

оборони України ім. І. Черняховського,

Київ, Україна

https://orcid.org/0000-0002-8553-9624

\section{Information about the authors:}

\author{
Nikolay Kachan \\ Senior Lecturer of Department \\ of Ivan Kozhedub Kharkiv \\ National Air Force University, \\ Kharkiv, Ukraine \\ https://orcid.org/0000-0003-3732-0369
}

\author{
Volodymyr Kulybaba \\ Postgraduate Student of the National Defence University \\ of Ukraine named after Ivan Cherniakhovskyi, \\ Kyiv, Ukraine \\ https://orcid.org/0000-0002-8553-9624
}


Байдацький Володимир Петрович слухач Національного університету оборони України ім. І. Черняховського, Київ, Україна https://orcid.org/0000-0001-6398-9192

\section{Білоус Володимир Богданович} слухач Національного університету оборони України ім. I. Черняховського, Київ, Україна https://orcid.org/0000-0003-4061-3445

Бойко Олександр Анатолійович слухач Національного університету оборони України ім. І. Черняховського, Київ, Україна https://orcid.org/0000-0003-1068-8390
Volodymyr Baidatskyi

Postgraduate Student of the National Defence University of Ukraine named after Ivan Cherniakhovskyi,

Kyiv, Ukraine

https://orcid.org/0000-0001-6398-9192

\section{Volodymyr Bilous}

Postgraduate Student of the National Defence University of Ukraine named after Ivan Cherniakhovskyi,

Kyiv, Ukraine

https://orcid.org/0000-0003-4061-3445

\section{Oleksandr Boiko}

Postgraduate Student of the National Defence University of Ukraine named after Ivan Cherniakhovskyi,

Kyiv, Ukraine

https://orcid.org/0000-0003-1068-8390

\section{НАУЧНО-МЕТОДИЧЕСКИЙ АППАРАТ УПРАВЛЕНИЯ СИСТЕМОЙ ГЕОПРОСТРАНСТВЕННОЙ РАЗВЕДКИ С ИСПОЛЬЗОВАНИЕМ СИСТЕМНО-КОГНИТИВНОГО АНАЛИЗА}

М.В. Качан, В.В. Кулибаба, В.П. Байдацкий, В.Б. Билоус, А.А. Бойко

На практике постоянно возникает проблема сочетания данных от различных видов разведки, чтобы получить максимально полную, точную и достоверную информацию. Данную проблему решает геопространственная разведка. Это в свою очередь требует соответствующего уровня автоматизации процеессов управления, добычей и обработки данных. В статье предложен научно-методический аппарат с использованием системно-когнитивного анализа для определения векторного критерия при решении задачи устойчивого управления, определения ценности и влияния входных параметров на функичиоирование и выбора стратегии управления системой геопространственной разведки.

Ключевые слова: автоматизация управления, данные, информация, система геопространственной разведки, разведывательные материаль, сведения.

\section{SCIENTIFIC AND METHODICAL APPARATUS FOR GEOPATRIC EXPLORATION SYSTEM MANAGEMENT SYSTEM-COGNITIVE ANALYSIS}

N. Kachan, V. Kulybaba, V. Baidatskyi, V. Bilous, O. Boiko

Modern scientific approaches to building a comprehensive assessment of the quality of automated control are not possible without the use of systematic analysis methodology. System analysis provides the completeness and comprehensiveness of the study of a complex system, allows you to combine into a whole set of processes that occur in different fields, such as economic, social, environmental, military. Today, all the links between complex military systems are poorly formalized and generally investigated. At the same time, the complex system itself is poorly structured and interconnected. On this basis, the authors propose the use of system-cognitive analysis to describe and study such systems. The Geospatial Intelligence system is an integral part of the military intelligence system and the overall monitoring system of Ukraine's allies, coalitions and blocs, and there are profunctions that are detailed into a typical set of tasks performed through the composition of internal functions and basic information-technological algorithms of system functioning. In turn, the automation of the Geospatial Intelligence is aimed at improving the efficiency of the system as a whole. In the development of an automated control system for the Geospatial Intelligence, the priority is to build a correct mathematical model of the control object. It is shown that the Geospatial Intelligence system is a multi-purpose weakly structured system in which the deterministic and bifurcation stages are distinguished. Managing such a system is a multi-criteria task that is complicated by the need to take into account group preferences of decision-makers. The quality of the decision support problem in the management process cannot be evaluated by one function or even by several scales. In such cases, the rational choice mechanism requires additional indirect information, which allows at least to compare alternatives to the choice of management strategies. Therefore, it is necessary to formulate and solve the problem of steady control of the system of Geospatial Intelligence in different conditions and states of its functioning on the basis of system-cognitive analysis. Theoretical studies of computational methods of decision theory prove the importance of determining the requirements for the procedure for forming a vector criterion. These requirements include the completeness of the set of criteria, the redundancy, the ability to decompose, the minimum, the ability to measure. The procedure for constructing such a vector criterion is quite complex, ambiguous and sometimes unformalized. The purpose of the article. The purpose of the article is to improve the scientific and methodological apparatus based on the use of system-cognitive analysis to determine the vector criterion in solving the problem of steady control, determine the value and influence of input parameters on the functioning and choice of strategy management of the Geospatial Intelligence system.

Keywords: data, geospatial intelligence system, information, intelligence materials, management automation. 